\title{
Peer review and critical thinking in nursing students
}

\author{
Rainho, Conceição ${ }^{\text {a }}$; Monteiro, Maria João ${ }^{\text {a }}$; Mártires, Alice ${ }^{\text {a }}$; Castelo-Branco, Zita ${ }^{\text {a }}$ \\ and Payan-Carreira, Rita ${ }^{\text {b }}$
}

${ }^{a}$ Escola Superior de Enfermagem de Vila Real, Universidade de Trás-os-Montes e Alto Douro, Portugal, ${ }^{\mathrm{b}}$ Escola de Ciências Agrárias e Veterinárias, Universidade de Trás-osMontes e Alto Douro, Portugal.

\begin{abstract}
Different models are available to help engage and motivate students as well as to model professional thinking and action. Their effect increases when regularly used, particularly when supplemented with feedback. Among them, the Paul-Elder's Elements of Thought, or the Ennis's FRISCO guidelines may be used for develop clinical skills. The objective of this study is describe the effect of educational intervention on critical thinking, in nursing students of the 2nd year, based on the peer review, using the Cornell test (Level X) before and after the activity. Of the 74 students who participated in the study, $75.7 \%$ were female with an average age of 20.8 years. The average scores of critical thinking before intervention was 21.3 and after was 28.5, the average was statistically significant different between the two time points $(p<0.01)$.
\end{abstract}

Keywords: Critical thinking, Cornell test, nursing student. 


\section{Introduction}

Critical thinking is one of the basic skills in clinical reasoning process in health (CrosKerry, 2012), and therefore essential to its development in the nursing students during the academic course (Facione \& Facione, 2008). It considers that competent nurses based on their professional activity in philosophy and thinking, rooted in concepts of critical thinking. In an attempt to define critical thinking, we find different approaches, from which we highlight two: a first focused on activities associated with critical thinking, and other skills or sub-competencies associated with this construct. Critical thinking is multidimensional, covering the cognitive (logical, rational), psychology (self-awareness, empathy), sociological (in terms of socio-historical context), ethics (standards and moral evaluation) and philosophical (meaning of human nature and life) (Paul, Elder \& Bartell, 1997).

Critical thinking is defined as the intellectually disciplined process of actively and skilfully conceptualizing, applying, analysing, synthesizing, in which the individuals develop the following characteristics: open to new ideas, flexible, willing to change, innovative, creative, analytical, communicators, assertive, observant, intuitive (Elder and Paul 2008; Ignatavicius, 2001).

Critical thinking in nursing is directed to clinical decision-making corresponding to the ability to think in a systematic and logical manner, open to the questioning of the thought process. This way of thinking, rigorous, rational, critical, based on scientific evidence, it is fundamental to nursing care. The studies emphasize the need for greater investment in promoting development strategies and evaluation of critical thinking, both in academic training as a professional (Amorim \& Silva, 2014). The practice of nursing is developing gradually of a paradigm based on experience for reflective and analytical practice that has allowed the affirmation of autonomous intervention of the profession and the development of a body of knowledge itself of the nursing discipline. Because its object is the care, recognizes the interdisciplinary responses to the needs of people in health care.

\section{Objectives}

This study aims to describe the effect of educational intervention on critical thinking, in nursing students of the 2 nd year, based on the peer review, using the Cornell test (Level $\mathrm{X}$ ) before and after the activity. 


\section{Methods}

This is a quantitative study, longitudinal and of the 84 students of Nursing Degree attending the subject Introduction to Health Research, 74 agreed to participate in the study. All students were invited to participate, after explaining the objectives of the study, after obtaining informed consent.

Different activities were developed between the two moments of data collection. A training activity at the beginning of the intervention through which we intend to sensitize students to the importance of peer review and feedback to improve learning. The intervention consists of peer review, in which groups of four students were authors and reviewers of a scientific paper, using the strategy of a cycle author/reviewer to develop written communication skills and critical thinking, according to the taxonomy proposed by Ennis $(1985,1987)$.

The FRISCO guidelines were developed by Ennis (1996) as standard criteria to support the critical thinking process, providing guidance for structured reasoning and problem analysis; it is used also for fostering individual's learning abilities under structured pedagogical situations (Dominguez et al., 2014). The acronym stands for Focus, Reasons, Inferences, Situation, Clarity and Overview.

The Cornell Critical Thinking Test (Level X) is based on critical thinking design defined by Ennis (1985). The Portuguese version of Cornell Test Critical Thinking (Level X) was apllied (Oliveira, 1992; Tenreiro-Vieira, 1994; Vieira, 1995, as cited in Tenreiro-Vieira, 2004). The test consists of 76 items and measures different aspects of critical thinking as: induction; credibility; deduction and identification of assumptions. This test was applied before the intervention student author - reviewer (moment 1). Once completed the tasks of student author - reviewer, the Cornell test (Level X), was again applied (moment 2), in order to check whether there was any change in developing some skills of critical thinking. Higher score after the process represents an increase of the level of critical thinking.

The activity was supported by an online environment (Google Drive), to provide the scientific paper, a template to write the work and a document that guide the students. The strategy reviewer/author of the paper as shown in Figure 1. 


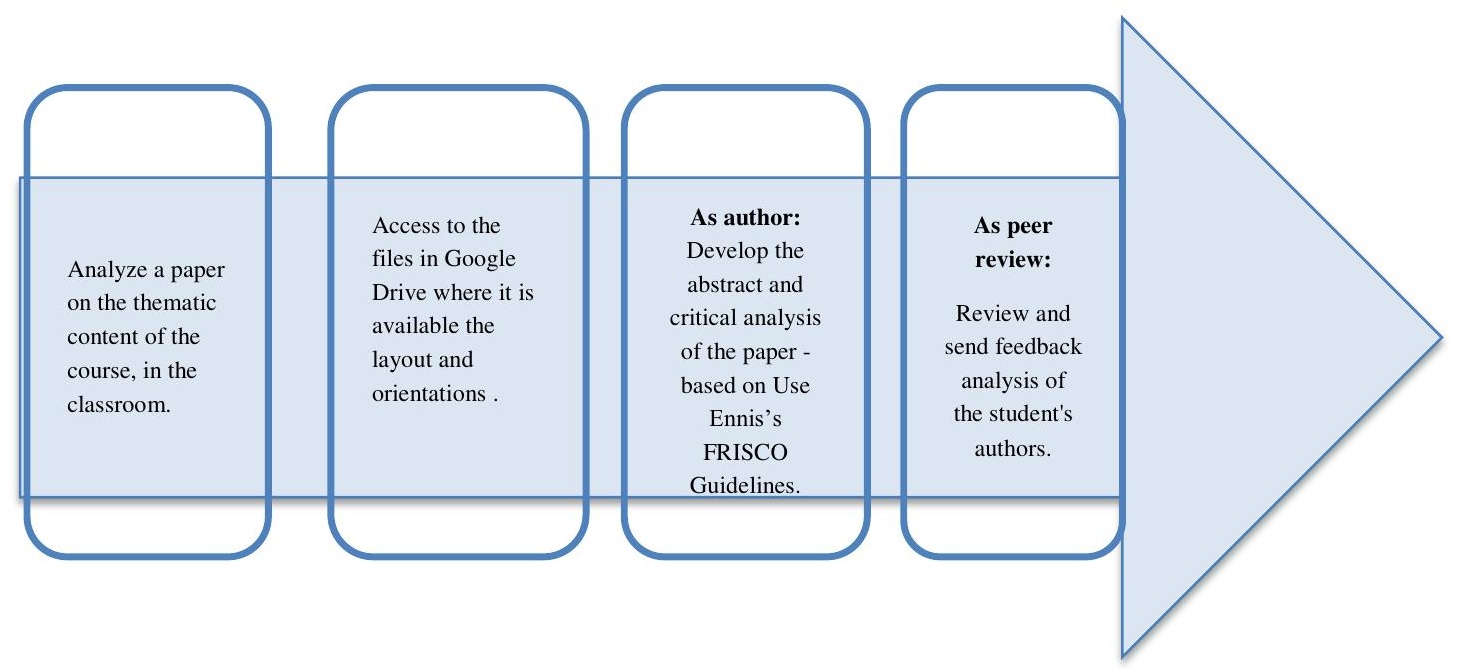

Figure1. Scheme of tasks to be performed by student author - reviewer. Source: Adapted from-Payan-Carreira,

Dominguez and Nascimento, 2014.

The work took place anonymously, not being revealed the author and reviewer groups; the wording of the text was not rigid, depending on personal preferences and styles; It was recommended bettween 500 e 1500 words.

For the statistical analysis we used the Statistical Package for Social Sciences (SPSS) version 22. We used descriptive statistics to characterize the group of students and effect evaluation of the intervention was based on the model proposed by Cohen (1992) for determining the magnitude of impact in groups of students, through Effect Size d Cohen test.

\section{Results}

Of the 74 students who participated in the study, $75.7 \%$ were female, and the average of age was 20.8 years. The average scores of critical thinking before intervention was 21.3 and after was 28.5 , the average was statistically significant different between the two time points $(\mathrm{p}<0.01)$.

Cornell test results show that on average each competency of critical thinking, increases the momento1 for the moment 2 (after intervention), as shown in table 1. 
Table 1. Means in the two moments (Cornell Test X)

\begin{tabular}{lcc}
\hline \multicolumn{1}{c}{ Variable } & $\begin{array}{c}\text { Mean } \\
\text { (moment 1) }\end{array}$ & $\begin{array}{c}\text { Mean } \\
\text { (moment 2) }\end{array}$ \\
\hline Induction & 8,622 & 9,432 \\
Deduction & 7,034 & 11,676 \\
Credibility & 5,804 & 7,196 \\
Identification of Assumptions & 1,041 & 3,8378 \\
Total Score & 21,304 & 28,493 \\
\hline
\end{tabular}

However only the statistically significant differences $(\mathrm{p}<0.01)$ were observed in relation to the size deduction (dCohen 0.95) and identification of assumptions (dCohen 1.16). The effect size is great for these two dimensions. The Percentile Gain for deduction is 33 and for identification of assumptions is 38 . The effect size indicates to what extent it was found or not the acquisition of critical thinking skills, in students sample.

\section{Conclusions}

The results obtained in the Cornell test, before and after the intervention student author reviewer, in order to determine the effect on the level of critical thinking of nursing students revealed an increase in critical thinking skills when it comes to dimensions, deduction and identification of assumptions. Regarding the induction and credibility dimensions, although the results were positive, the averages were not statistically different, by suggesting the continuity of the study, replicating it in other student groups and possibly using other pedagogical strategies.

The peer review strategy is described in the literature as important to nursing, because facilitate and promote active learning, help clinical problem solving, and encourage the development of critical thinking skills. $\mathrm{n}$ the future "Nurses must think critically to provide effective care whilst coping with the expansion in role associated with the complexities of current health care systems" (Simpson and Courtney , 2002, p.89).

The results lead us to suggest that the anonymous peer review (author - reviewer) was welcomed by the students, analysis of the article led to the development of analytical capacity and promoted the exchange of views and joint progress in the presentation and 
defence of different perspectives on an epidemiological study, verifying a positive development especially in regard to the deduction of dimensions and assumptions.

\section{References}

Amorim, M.P., \& Silva, I. (2014). Instrumento de avaliação do pensamento crítico em estudantes e profissionais de saúde. Psicologia, Saúde \& Doenças, 15 (1), 122-137.

Carreira, R.P., Dominguez, C., \& Nascimento, M.M. (2014). Estratégias de reforço das capacidades de pensamento crítico: Um caso na UTAD. In C.A. Ferreira, A.M. Bastos \& H. Campos (Orgs.), Práticas educativas: Teorização e formas de intervenção (pp. 56-67). Vila Real: UTAD.

Cohen, J. (1992). A power primer. Psychological Bulletin, 112 (1), 155-159.

Croskerry, P. (2012). Perspectives on diagnostic failure and patient safety. Healthcar Quarterly, 15 (Special issue), 50-56. doi:10.12927/hcq.2012.22841

Dominguez, C., Nascimento, M.M., Payan-Carreira, R., Cruz, G., Silva, H., Lopes, J., ... Morais, E. (2014). Adding value to the learning process by online peer review activities: towards the elaboration of a methodology to promote critical thinking in future engineers. European Journal of Engineering Education, 40 (5), 573-591. doi: 10.1080/03043797.2014.987649

Elder, L., \& Paul, R. (2008). The thinker's guide to intellectual standards: The words that name them and the criteria that define them. The Foundation for Critical Thinking. Calif, USA: Dillon Beach.

Ennis, R.H. (1987). A taxonomy of critical thinking dispositions and abilities. In J.B. Baron \& R.J. Sternberg (Eds.), Teaching thinking skills: Theory and practice (pp. 9-26). New York: W. H. Freeman and Company.

Ennis, R.H., \& Millman, J. (1985). Cornell critical thinking test, level Z (3rd ed.). Pacific Grove, CA: Midwest.

Facione, N.C., \& Facione, P.A. (2008). Critical thinking and clinical judgment. In Critical thinking and clinical judgment the health science (pp. 1-13). Millbrae, CA: California Academic Press.

Ignatavicius, D. (2001). Critical thinking skills for at-the-bedside success. Nursing Management, 32 (1), 37-39.

Pinto, I. R. F. (2011). Atividades promotoras de pensamento crítico: Sua eficácia em alunos de ciências da natureza do $5 .^{\circ}$ ano de escolaridade. Dissertação de mestrado não publicada, Instituto Politécnico de Lisboa.

Silva, E.R. (2008). Desenvolvimento do pensamento crítico: Uma ferramenta essencial para os profissionais de saúde. Scientia Médica, 18 (3), 108-109.

Simpson, E., \& Courtney, M.D. (2002). Critical thinking in nursing education: a literature review. International Journal of Nursing Practice 8 (4), 89-98. 
Tenreiro-Vieira, C. (2004). Produção e avaliação de actividades de aprendizagem de ciências para promover o pensamento crítico dos alunos. Revista Iberoamericana de Educación, 33 (6). Retrived: http://www.campusoei.org/revista/deloslectores/ 708.PDF 